\title{
Thermodynamic modeling in solving some issues of inland saline ecosystems
}

\author{
Olga L. Gaskova ${ }^{1,2^{*}}$, and Vera D. Strakhovenko ${ }^{1,2}$ \\ ${ }^{1}$ Sobolev Institute of Geology and Mineralogy SB RAS, 630090 Novosibirsk, Russia \\ ${ }^{2}$ Novosibirsk State University, 630090 Novosibirsk, Russia
}

\begin{abstract}
The purpose of this work was to show some examples of using thermodynamic modeling to understand quantitatively the water-rock interaction processes in salt lakes systems. The systems of small lakes located compactly are convenient to comparative modeling, because this permits minimization of the number of variables in the model (the climatic, geomorphological and geological specifics, water balance in the same watershed area). Nevertheless, it turns out that each lake is a relatively autonomous system (natural biogeocenosis, formed as a result of diagenesis). Due to the conjugate processes of biogenic and inorganic interactions, they are in a steady state, which has been fixed during the geochemical sampling in the field.
\end{abstract}

\section{Introduction}

There is a need to describe the geochemical behavior of the saline systems (e.g., species of multicomponent aqueous systems and salt-solution equilibria) in order to provide keys of understanding the problems of climate change, the evolution of the environment, the conservation of natural resources. Along with the task of quantitative description of waterrock processes in the salt lakes systems, there is an inverse aspect of physicochemical modeling. Because of calculating the phase equilibria in the model system, we obtain the stability fields of all minerals whose thermodynamic potentials are included in the database. Thus, we can predict the physicochemical conditions for the formation of all solid phases, the formation of which is established during the modeling study [1].

The purpose of this work was to show some examples of using the results of thermodynamic modeling to solve the above-indicated questions. The systems of small lakes located compactly in the area are convenient to use as model natural objects.

The lakes Kambala and Barchin (Baraba steppe, Southern West Siberia, Russia) are characterized by the deposition of organic-rich sediment known as sapropel. The reasons for the sapropel formation "remain a long-standing debate in the science community, and require disentangling the roles of climatic/oceanographic processes that triggered higher primary productivity or enhanced organic matter $(\mathrm{OM})$ preservation" [2].

Detailed hydrochemical sampling of two small soda lakes with the same name (Lakes Petukhovo) and different chemical composition of water in the Kulunda steppe, located at a

* Corresponding author: gaskova@igm.nsc.ru 
distance of $14 \mathrm{~km}$ from each other, provided answers to many questions. The lakes have $\mathrm{pH}$ $>9$ and thus they are soda type [3].

The microbiologic factors governing sedimentation in limnological systems are also yet to be elucidated [4]. The Tsagan-Tyrm and Namshi-Nur lakes (Tazheran steppe, Cisbaikalia) differ greatly in water salinity, they have high uranium contents both in the waters and in the bottom sediments, and are located at $2 \mathrm{~km}$ from each other.

\section{Methods}

Bottom sediment columns were taken from a catamaran by means of a cylindrical sampler with a vacuum seal designed by the Taifun Science and Production Enterprise. Sampling of water for all analyzes was performed according to the standard GOST 31861 technique. The $\mathrm{pH}$ and Eh values, total mineralization, and oxygen content of the water were determined in the field. The water and bottom sediment samples were analyzed for trace and major elements by AAS with flame and electrothermal atomization (Solaar M6 Thermo Electron spectrometer (England) equipped with Zeeman and deuterium background correction systems). The X-ray diffraction method (XRD) was applied to analyze the mineral composition of the bottom sediments (ARLX'TRA diffractometer with CuK $\alpha$ radiation). The morphology and phase and chemical compositions of the samples were studied with a LEO1430VP scanning electron microscope equipped with an OXFORD energy dispersive spectrometer. The $U$ isotopes were determined by high-resolution semiconductor gamma spectrometry with a well semiconductor detector (SCD). These data were used to develop thermodynamic models in this paper [5-7].

The equilibria in the heterophase 18-component system H-O-C-S-Cl-N-Ca-Mg-Na-K$\mathrm{Fe}-\mathrm{Mn}-\mathrm{Al}-\mathrm{Si}-\mathrm{Sr}-\mathrm{Cu}-\mathrm{Zn}-\mathrm{U}$ were calculated at $25^{\circ} \mathrm{C}$, total pressure of $1 \mathrm{~atm}$, and partial $\mathrm{CO}_{2 \text { (gas) }}$ pressure of $10^{-3.5}-10^{-2.5} \mathrm{~atm}$, using the $\mathrm{HCh}$ (HydroChemistry) software based on the principle of minimization of the thermodynamic potentials of the system (Gibbs free energy) and containing the UNITHERM database [8]. The database was supplemented with the consistent values of the free energy of formation of evaporite minerals. The mineral saturation indices (SI) of brines were calculated as the ratios of the ion activity products to the mineral solubility product. The condition for equilibrium is $\operatorname{logSI}=0$ ( \pm 0.2 units). The activity coefficients were calculated by the Debye-Hückel equation of third approximation; for high mineralized solutions, they were calculated by the equation of Helgeson et al. [9].

\section{Results}

\subsection{The reduced environment of lake bottom sapropel formation}

More than 20000 lakes with sapropel are located in southern West Siberia. The Kambala and Barchin brackish lakes (Baraba steppe) contain an organic-rich sapropel bottom sediment. The studied lakes are small in area, and their depth is no more than $3 \mathrm{~m}$. The hostrocks are characterized as loess-like clay loams and lake clay alluvium. An interesting feature of these bicarbonate-sodium lakes is biota diversity, but the precise reason for this phenomenon is not known. Diatoms are among the most common types of phytoplankton in the Kambala Lake. The diatom cells incorporate skeletons composed of hydrated $\mathrm{SiO}_{2}$, so this lake contains siliceous type sapropel $\left(34.1 \% \mathrm{SiO}_{2}\right.$ and $2.6 \% \mathrm{CaO}$ ). Small-celled colonial calcareous cyanobacteria capable of depositing calcium carbonate sharply dominate in the Barchin Lake with calcium type sapropel $\left(11.2 \% \mathrm{SiO}_{2}\right.$ and $19.8 \% \mathrm{CaO}$ ). The mineral part of the Barchin Lake sapropel consists of low-Mg calcite up to $80 \mathrm{wt} . \%$, quartz, pyrite, aragonite $\sim 3 \%$. Aragonite originates from the shells of various shellfish and 
it is absent in the siliceous sapropel of the Kambala Lake. The main species of zooplankton in the Kambala Lake was large filtering Cladocera, whereas Rotifera dominated in the Barchin Lake. Zooplankton active life is the cause of the high content of Humic Substances (HS) in the Kambala Lake sapropel (38\%) contrary to the Barchin Lake (18\%). The studied lakes are characterized by the abundant bacteria of the genus Sphaerotilus, which reduce $\mathrm{Fe}(\mathrm{III})$, and sulfate-reducing bacteria (SRB). Pyrite was found in both lakes in the first $\mathrm{mm}$ of the sapropel-water surface.

The corresponding redox reaction could be modeled using $\mathrm{CH}_{2} \mathrm{O}$ as a generally accepted virtual component of OM and an electron donor (1). So simple model excluding the quality of OM (molecular weight and elemental composition) could only equilibrate the redox conditions without clarifying the exact mechanism of the observed phenomena.

$$
2 \mathrm{CH}_{2} \mathrm{O}+\mathrm{SO}_{4}{ }^{2-}+2 \mathrm{H}^{+}=2 \mathrm{CO}_{2}+2 \mathrm{H}_{2} \mathrm{O}+\mathrm{H}_{2} \mathrm{~S}
$$

The fresh lake Kambala water salinity $(0.53 \mathrm{~g} / \mathrm{L})$ has a $\mathrm{pH}$ of 9.3 , Eh $0.3 \mathrm{~V}$, DOC content is $16.5 \mathrm{mg} / \mathrm{L}$. The water is slightly supersaturated with respect to quartz, calcite and magnesite. Traces of chlorite, goethite, $\mathrm{MnO}_{2}, \mathrm{SrCO}_{3}$ and $\mathrm{F}$-apatite occur in the model solid phase. The mineral composition of the bottom sediments has been recalculated according to $\mathrm{X}$-ray fluorescence and AAS analyses. The influence of OM was modeled by introducing of 1.5 gram of $\mathrm{CH}_{2} \mathrm{O}$ and $\mathrm{OM}$ oxidation causes precipitation of pyrite and other sulfides at pH 9.4 and Eh -0.4 V. Gypsum $\mathrm{CaSO}_{4} \cdot 2 \mathrm{H}_{2} \mathrm{O}$ was not found in the model association, although was identified in the low part of the Kambala sapropel sediments instead of lowMg calcite.

The Barchin Lake fresh water has a salinity of $0.57 \mathrm{~g} / \mathrm{L}$ and a $\mathrm{pH}$ of 8.9, Eh $0.3 \mathrm{~V}$, DOC content is $26.6 \mathrm{mg} / \mathrm{L}$. Thermodynamic calculations have shown that there are no major differences in the composition of the minerals to which the Barchin Lake water is supersaturated in comparison with the Kambala Lake (only their proportions differ greatly). These are mainly low-Mg calcite, minor quartz, trace of goethite and chlorite; OM oxidation causes precipitation of pyrite and other sulfides at $\mathrm{pH} 8.9$ and $\mathrm{Eh}-0.3 \mathrm{~V}$. Surprisingly, silt water is in equilibrium with gypsum, that indicates the possibility of its presence in carbonate sapropel, although it has not yet been found in nature. Pyrite-gypsum equilibrium is important as an indicative of $\mathrm{HS}^{-} / \mathrm{SO}_{4}{ }^{2-}$ equilibrium. It is known, that pyrite is formed below the redox chemocline. Nevertheless, depending on the Eh, sulfate sulfur can dominate in solution, causing the formation of gypsum together with pyrite. The silt water is not necessarily euxinic (anoxic and sulfidic water). Our calculations show that at the measured $\mathrm{pH} \sim 9$, sulfate sulfur may prevail at $\mathrm{Eh} \geq(-0.3 \mathrm{~V})$. The partial pressure of oxygen can be calculated by the reaction (2):

$$
\mathrm{FeS}_{2}+2 \mathrm{CaCO}_{3}+2.75 \mathrm{O}_{2}+6.5 \mathrm{H}_{2} \mathrm{O}=\mathrm{Fe}(\mathrm{OH})_{3(s)}+2 \mathrm{CaSO}_{4} \cdot 2 \mathrm{H}_{2} \mathrm{O}+\mathrm{HCO}_{3}{ }^{-}+\mathrm{H}^{+}
$$

Thermodynamic calculations show that, based on the ionic composition of water, it is possible to predict the type of sapropel and to prove the need of reducing conditions for its preservation.

\subsection{The diversity of sediments from the two nearest soda lakes}

Lakes Petukhovo are located in the Kulunda steppe. The annual precipitation here is 230$350 \mathrm{~mm}$. Lake Petukhovo near Severka Village (the Pine-forest lake), with a water surface area of $\sim 5.3 \mathrm{~km}^{2}$ is located at an altitude of $146 \mathrm{~m}$. Lake Petukhovo near Petukhi Village (the Steppe lake), with a water surface area of $\sim 15 \mathrm{~km}^{2}$, is located within the Kulunda basin at an altitude of $125 \mathrm{~m}$. They differ in the composition of saline waters $\left(\mathrm{HCO}_{3}-\mathrm{Cl}-\mathrm{Na}\right.$ and $\mathrm{Cl}-\mathrm{SO}_{4}-\mathrm{Na}-\mathrm{Mg}$, TDS 24.3 and $26.1 \mathrm{~g} / \mathrm{L}$ respectively) and bottom sediments. The main 
minerals in the Pine-forest lake sediments are dolomite (especially in the lower part of the sediment core), quartz, disordered Ca-smectites; the impurities are halite, pyrite, barite. The minerals in the bottom sediments of the Steppe lake are dominated by quartz, feldspars, dolomite and $\mathrm{Mg}$-calcite, with the carbonates increasing in the lower part of the core; the impurities are Fe-hydroxides, anhydrite, calcite. Precipitation of soda $\left(\mathrm{Na}_{2} \mathrm{CO}_{3} \cdot 10 \mathrm{H}_{2} \mathrm{O}\right)$ and trona $\left(\mathrm{Na}_{2} \mathrm{CO}_{3} \cdot \mathrm{NaHCO}_{3} \cdot 2 \mathrm{H}_{2} \mathrm{O}\right)$ are indicative for both lakes. According to [10] "even with the same groundwater filtration through the bottom sediments, the lakes at the lower hypsometric level will have a higher content of chlorides and sulfates as compared with the upper lakes, where magnesium and calcium carbonates or even soda is precipitated".

Accumulations of anoxygenic phototrophic bacteria forming lilac-pink bacterial mats were observed in both lakes Petukhovo. Both lakes are mesotrophic. The microbial sulfur cycle is among the most active in soda lakes $[4,11]$. The Pine-forest lake water has a $\mathrm{pH}$ of 9.8, Eh $-0.2 \mathrm{~V}, \mathrm{Ca}$ content is $1, \mathrm{Fe}-1.4 \mathrm{mg} / \mathrm{L}$. A strong smell of hydrogen sulfide is on the shore. There is a water supersaturation with respect to dolomite, quartz, chlorite and goethite. Traces of $\mathrm{MnO}_{2}, \mathrm{SrCO}_{3}$, barite and F-apatite occur in the model solid phase. Pyrite does not appear in the calculations unlike the natural associations. It is likely that the main mechanism of its precipitation is an activity of the SRB that is also confirmed by the morphology of pyrite (characteristic globules). Ions behavior during model evaporation of the Pine-forest lake saline water was calculated: (a) as the amount of water decreases ten times, to $0.1 \mathrm{~kg}$, soda and trona appear; (b) when water decreases to $0.05 \mathrm{~kg}$, halite and even traces of burkeite $\mathrm{Na}_{6} \mathrm{CO}_{3}\left(\mathrm{SO}_{4}\right)_{2}$ could precipitate. Temperature fluctuations also affect the order of minerals precipitation: as the temperature decreases, the solubility of $\mathrm{CO}_{2 \text { (gas) }}$ increases and trona replaces soda. Ca-mectites do not appear in the calculations. Formation of the smectites requires a prolonged water-rock interaction time and saturation of the solution with many components [12]. Therefore, they might be produced not from the surface water but from the silt solutions in the process of bottom sediments diagenesis. Moreover, feldspars and dark-colored minerals intensively transform into smectites in the environment rich in dissolved OM [13].

The Steppe lake water has a $\mathrm{pH}$ of 9.5 , Eh $0 \mathrm{~V}$, Ca content is $69, \mathrm{Fe}-0.05 \mathrm{mg} / \mathrm{L}$, the high concentration of $\mathrm{Mg}$ is equal to $3700 \mathrm{mg} / \mathrm{L}$. There is a water supersaturation with respect to quartz and $\mathrm{Mg}$-calcite $-\mathrm{Ca}_{0.52} \mathrm{Mg}_{0.48} \mathrm{CO}_{3}, \mathrm{Mg}$-chlorite and goethite. The problem of supersaturation of the solution with magnesium species remains open. The bottom sediments of this lake are enriched with terrigenous minerals as compared with authigenic (chemogenic) minerals in the Pine-forest lake. The rate sedimentation, calculated based on ${ }^{210} \mathrm{~Pb}$ and ${ }^{137} \mathrm{Cs}$ contents, suggests that this change in the $\mathrm{Al}$ (an indicator of terrigenous minerals) and $\mathrm{Ca}$ (an indicator of authigenic minerals) throughout the sediment core was in

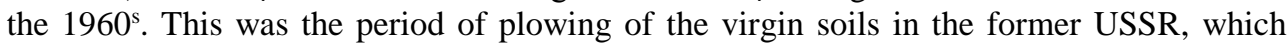
resulted in a drastic increase in the content of an aeolian component in the lake bottom sediments. Therefore, the landscape and technogenic factors can strongly influence the distribution of elements in the nearest lake systems (both in water and bottom sediments).

\subsection{Links between trace elements species and biogeochemical processes}

Lakes Tsagan-Tyrm and Namshi-Nur are located in the Tazheran steppe. They differ in the composition of alkaline $(\mathrm{pH} \geq 9)$ waters $\left(\mathrm{Cl}-\mathrm{SO}_{4}-\mathrm{HCO}_{3}-\mathrm{Na}\right.$ and $\mathrm{HCO}_{3}-\mathrm{SO}_{4}-\mathrm{Cl}-\mathrm{Na}-\mathrm{Mg}$, TDS 20 and $2.1 \mathrm{~g} / \mathrm{L}$ respectively). The bottom sediments of studied lakes accumulate $\mathrm{OM}$ and carbonates but in different amounts and of different stoichiometric compositions. The reducing conditions in the upper horizons of sediments in both lakes are evidenced by the presence of framboidal pyrite. The carbon isotope composition $\left(\delta^{13} \mathrm{C}_{\mathrm{PDB}}\right)$ of the $\mathrm{OM}$ varies from -13.8 to $-26.4 \%$. This proves that most of the $\mathrm{OM}$ forms with the participation of aquatic microorganisms. The $\delta^{13} \mathrm{C}$ values of carbonates of the Tazheran lakes vary as 
follows: $\delta^{13} \mathrm{C}$ carb -23.6 to $-3.9 \%$. This means that carbon dioxide was produced through the bacterial destruction of $\mathrm{OM}$ for the carbonates precipitation. The ${ }^{234} \mathrm{U} /{ }^{238} \mathrm{U}$ ratio in the Tsagan-Tyrm and Namshi-Nur waters is 2.7 and 1.7 due to a uranium isotope disbalance in the surface waters; these ratios correspond to those in bottom sediments. Thermodynamic models have been developed to confirm the distribution of $\mathrm{U}, \mathrm{Mn}$, and Fe to the depth of bottom sediments depending on the redox potential and carbonate composition. Alternatives to the biogenic and chemogenic reduction/oxidation of these elements are discussed.

\section{Conclusions}

Thermodynamic calculations show that, based on the ionic composition of water, it is possible to predict the type of bottom sediments, the species of elements in the solutions of variable Eh-pH, to simulate the direction of the sedimentation process during evaporation or temperature fluctuations. At the same time, each lake is a relatively autonomous system and many local factors can strongly influence the redistribution of elements in the nearest lake systems.

This study was financially supported by the Russian Science Foundation (OLG, Project 18-77-10029, thermodynamic modelling); work is done on State assignment of the IGM SB RAS and financially supported by the Russian Foundation for Basic Research (VDS, Project 16-05-00132, field sampling and chemical analyses).

\section{References}

1. V.G. Krivovichev, M.V. Charykova, Geol. Ore Depos., 59, 575 (2017)

2. J. Plancq, V. Grossi, B. Pittet, C. Huguet, A. Rosell-Melé, E. Earth Planet. Sci. Lett., 420, 30 (2015)

3. M.N. Kolpakova, O.L. Gaskova, Hydrology Res., 49, 163 (2018)

4. G.A. Zavarzin, Lectures on Natural Microbiology [in Russian] (Nauka, Moscow, 2004)

5. O.L. Gaskova, V.D. Strakhovenko, N.I. Ermolaeva, E.Yu. Zarubina, E.A. Ovdina, Chinese J. Oceanol. Limnol., 35 (2017), 956

6. O.L. Gas'kova, V.D. Strakhovenko, E.A. Ovdina, Russ. Geol. Geophys., 58, 1199 (2017)

7. V.D. Strakhovenko, O.L. Gas'kova, Russ. Geol. Geophys., 59, 374 (2018)

8. Y.V. Shvarov, Geochem. Intern., 46, 834 (2008)

9. H.C. Helgeson, D.H. Kirkham, G.H. Flowers, Am. J. Sci., 281, 1249 (1981)

10. M.P. Lebedeva, O.V. Lopukhina, N.V. Kalinina, Eurasian Soil Sci., 41, 416 (2008)

11. D.Y. Sorokin, J.G. Kuenen, G. Muyzer, Front. in Microbiology, 2, 2 (2011)

12. S.L. Shvartsev, Hydrogeochemistry of Hypergenesis Zone [in Russian]. (Nedra, Moscow, 1998).

13. K. Wallmann, G. Aloisi, M. Haeckel, P. Tishchenko, G. Pavlova, J. Greinert, S. Kutterolf, A. Eisenhauer, Geochim. Cosmochim. Acta, 72, 3067 (2008) 